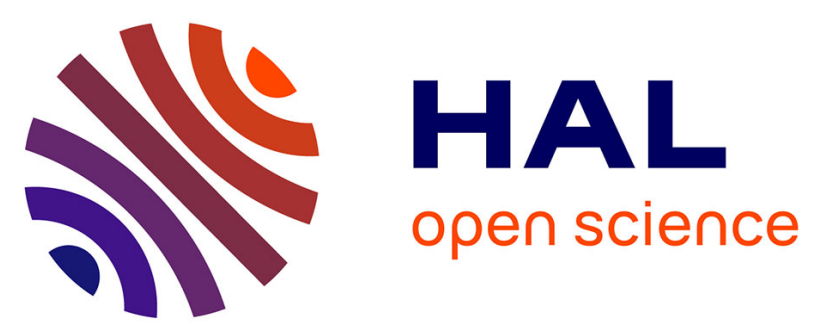

\title{
High-power diode-pumped cryogenically cooled Yb:CaF2 laser with extremely low quantum defect
}

Sandrine Ricaud, Dimitris N. Papadopoulos, Alain Pellegrina, François

Balembois, Patrick Georges, Antoine Courjaud, Patrice Camy, Jean-Louis

Doualan, Richard Moncorgé, Frédéric Druon

\section{To cite this version:}

Sandrine Ricaud, Dimitris N. Papadopoulos, Alain Pellegrina, François Balembois, Patrick Georges, et al.. High-power diode-pumped cryogenically cooled Yb:CaF2 laser with extremely low quantum defect. Optics Letters, 2011, 36 (9), pp.1602-1605. hal-00588873

\section{HAL Id: hal-00588873 \\ https://hal-iogs.archives-ouvertes.fr/hal-00588873}

Submitted on 26 Apr 2011

HAL is a multi-disciplinary open access archive for the deposit and dissemination of scientific research documents, whether they are published or not. The documents may come from teaching and research institutions in France or abroad, or from public or private research centers.
L'archive ouverte pluridisciplinaire HAL, est destinée au dépôt et à la diffusion de documents scientifiques de niveau recherche, publiés ou non, émanant des établissements d'enseignement et de recherche français ou étrangers, des laboratoires publics ou privés. 


\title{
High-power diode-pumped cryogenically-cooled Yb:CaF 2 laser with extremely low quantum defect
}

\author{
S. Ricaud ${ }^{1,4, *}$, D. N. Papadopoulos ${ }^{2}$, A. Pellegrina ${ }^{2}$, F. Balembois ${ }^{1}$, P. Georges ${ }^{1}$, A. Courjaud ${ }^{4}$, \\ P. Camy ${ }^{3}$, J. L. Doualan ${ }^{3}$, R. Moncorgé ${ }^{3}$, F. Druon ${ }^{1}$, \\ 1. Laboratoire Charles Fabry de l'Institut d'Optique, UMR 8501 CNRS, Université Paris Sud, 91127 Palaiseau, France \\ 2. Institut de la Lumière Extrême, CNRS, Ecole Polytechnique, ENSTA Paristech Institut d'Optique, Université Paris Sud, \\ Palaiseau Cedex, France \\ 3. Centre de recherche sur les Ions, les Matériaux et la Photonique (CIMAP), UMR 6252 CEA-CNRS-ENSICaen, \\ Université de Caen, 14050 Caen, France \\ 4. Amplitude Systèmes, 6 allée du doyen Georges Brus, 33600 Pessac, France \\ *Corresponding author: sandrine.ricaud@institutoptique.fr \\ Received Month X, XXXX; revised Month X, XXXX; accepted Month X, \\ XXXX; posted Month X, XXXX (Doc. ID XXXXX); published Month X, XXXX \\ High-power diode-pumped laser operation at $992-993 \mathrm{~nm}$ under a pumping wavelength $981 \mathrm{~nm}$ or $986 \mathrm{~nm}$ is demonstrated \\ with $\mathrm{Yb}: \mathrm{CaF}_{2}$ operating at cryogenic temperature $(77 \mathrm{~K})$ leading to extremely low quantum defects of $1.2 \%$ and $0.7 \%$, \\ respectively. An average output power of $33 \mathrm{~W}$ has been produced with an optical efficiency of $35 \%$. This represents the best \\ laser performance ever obtained at such low quantum defects on intense laser lines. \\ OCIS Codes: $140.3615,140.3380,140.3480,140.3580$
}

Doped fluoride crystals have been known and identified as attractive laser media since the very beginning of the lasers [1]. In the field of ultrahigh-peak power laser with high repetition rate, very interesting laser development at cryogenic temperature has been done with $\mathrm{Yb}: \mathrm{YLF}[2,3]$ and $\mathrm{Yb}: \mathrm{CaF}_{2}[4,5]$. In the case of $\mathrm{Yb}: \mathrm{CaF}_{2}$, crystallographic and luminescence properties were already known a long time ago [6]. However, the characteristics of these materials have not been fully exploited, especially at high dopant concentration [7-10]: a broad emission band, a long emission lifetime of $2.3 \mathrm{~ms}$, with moreover a good thermal conductivity $[11,12]$ and at last, but not least, a wellmastered growing process for high-quality and large single crystals. Thus, Yb doping now allows calcium fluoride to strike back for high power laser applications; they indeed become in few years among the most promising laser materials for high-energy/high-power diode-pumped laser systems [13-16].

In this letter we present another typical property of $\mathrm{Yb}: \mathrm{CaF}_{2}$, which allows for efficient laser emission in a "quasi-two-level" laser scheme without any ultra wavelength-selective or narrow-linewidth intracavity element. This could represent a breakthrough for ultrahigh-power lasers since it could lead both to efficient diode-pumped laser operation and to a minimal thermal load [5,17-19]. Moreover, as this quasi-two-level laser system operates at cryogenic temperature, it brings another positive advantage for high power laser devices, which consists in improving the thermal properties of the laser element such as its thermal conductivity.

$\mathrm{Yb}^{3+}$ has a simple electronic-level structure based on only two manifolds $\left(2 \mathrm{~F}_{7 / 2}\right.$ and $\left.2 \mathrm{~F}_{5 / 2}\right)$ which splits into different crystal-field Stark sublevels whose number and energy separation depend on the symmetry and the strength of the local crystal-field environment. Due to charge compensation and minimum-energy arrangements of the ions in this system [6], the case of heavily doped $\mathrm{Yb}: \mathrm{CaF}_{2}$ is very particular. Indeed, the luminescent centers, responsible for the laser properties of the material, give rise to a typical relatively weak crystalfield and reduce crystal-field splittings of the $\mathrm{Yb}^{3+}$ energy levels (see in Fig. 1a).

Consequently, in addition to the broad-band vibronic structure, which extends from about 1000 to $1060 \mathrm{~nm}$, and to the zero-phonon lines (corresponding to the socalled "zero-line" around $981 \mathrm{~nm})$, there is another set of clear lines at 985.2 and $991.5 \mathrm{~nm}$ with substantial emission/absorption cross sections. They correspond to zero-phonon transitions from the lowest ${ }^{2} \mathrm{~F}_{5 / 2}$ (emitting level at about $10200 \mathrm{~cm}^{-1}$ ) to the second and third energy levels of the ${ }^{2} \mathrm{~F}_{7 / 2}$ ground multiplet (around 50 and $110 \mathrm{~cm}^{-1}$ ), respectively.
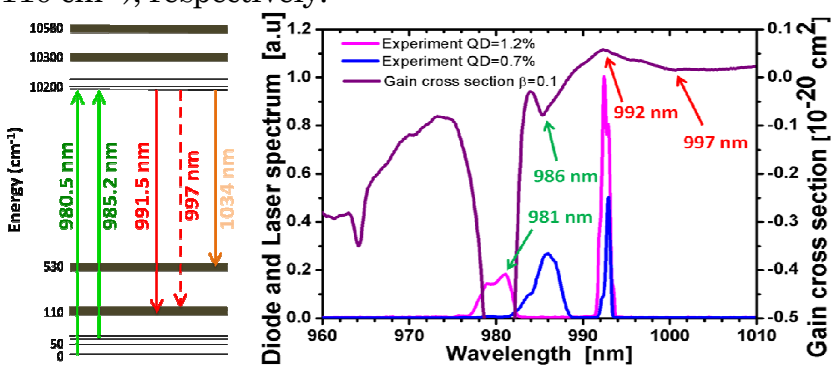

Fig. 1a Spectroscopic lines of $\mathrm{Yb}: \mathrm{CaF}_{2}$ at $77 \mathrm{~K}$, (b) Experimental measurements of pump and laser wavelengths for pumping at $981 \mathrm{~nm}$ (blue curve) or $986 \mathrm{~nm}$ (red curve); and gain cross section of the $\mathrm{Yb}: \mathrm{CaF}_{2}$ at $77 \mathrm{~K}$ and for $\beta=0.1$ (purple curve).

Thus, laser operation at short-wavelength and "ultralow quantum-defect" is possible by cooling the laser crystal down to Liquid Nitrogen $\left(\mathrm{LN}_{2}\right)$ temperature, as presented in the letter.

The experiments were performed with a $2.2^{-} \%{ }^{-} \mathrm{Yb}^{-}$ doped, 5-mm-long fluorite crystal. The experimental setup is displayed in Fig. 2. In order to pump the crystal longitudinally and to allow simultaneously an extremely short wavelength separation between pump and laser, a 
broadband HR mirror of 2-mm-diameter glued on a 25 $\mathrm{mm}^{-}$diameter AR plate is implemented. This pump-beamocculting mirror uses the advantage of the large diameter pump beam (collimated fiber-coupled laser diode with NA $=0.22$ ) compared to the laser beam inside the $\mathrm{Yb}: \mathrm{CaF}_{2}$ laser resonator, forming as a so-called modal multiplexer. The corresponding losses observed on the pump beam do not exceed 4\%. Moreover, the laser is free from any spectral selection and operates very efficiently at its maximum spectral gain without additional losses.

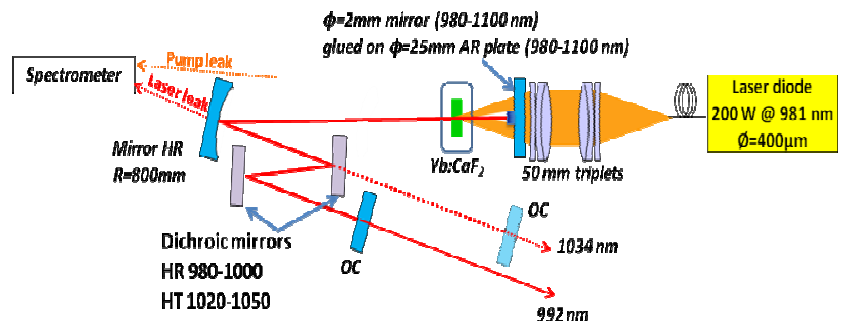

Fig.2: Experimental setup.

According to the emission and absorption spectra of $\mathrm{Yb}: \mathrm{CaF}_{2}$ registered at low temperature [5], the laser should have naturally operated, without extra wavelength selector, at $992 \mathrm{~nm}$ for an inversion population $(\beta)$ higher than $10 \%$. However, it is not the case, since laser operation remains fixed at $1034 \mathrm{~nm}$, even for an average inversion population higher than $40 \%$. This is probably due to uncertainty on the temperature elevation in the crystal. In order to favor the short wavelengths emission with a minimum of losses, we insert in the cavity (Fig. 2) a wavelength selector consisting of two high-pass dichroic mirrors highly reflective between 980 and $1000 \mathrm{~nm}$ with losses per bounce $<0.1 \%$ at $992 \mathrm{~nm},<1 \%$ at $997 \mathrm{~nm}$ and a high transmission (>95\%) around $1030 \mathrm{~nm}$. Consequently, the impact of this selector is acceptable and allows efficient laser at low wavelengths. In these conditions, laser operation occurs between around $992 \mathrm{~nm}$ and 997 nm.

Figure 3a displays the output power obtained for different output couplers. Thereby, we determine the spectral gain of the crystal at varying population inversion levels, estimated using the following equation:

$$
\left(1-T_{o c}-L\right) \exp \left(\left(\beta \sigma_{e m}+(1-\beta) \sigma_{a b s}\right) N \ell\right)=1 \quad \text { Eq. } 1
$$

where $\mathrm{N}$ is the $\mathrm{Yb}$-dopant concentration, $\sigma_{\mathrm{em}}, \sigma_{\mathrm{abs}}$ are the emission and absorption cross sections at the laser wavelength $\left(\lambda_{\mathrm{L}}\right), \ell$ is the length of the crystal, Toc is the output coupler transmission and L the losses (vs $\lambda_{\mathrm{L}}$ ).

At low inversion $\left(\beta<0.05\right.$, e.g. $\left.\mathrm{T}_{\mathrm{oc}}=5 \%\right)$, only $997 \mathrm{~nm}$ is observed, whereas at intermediate levels $(0.05<\beta<0.08)$ the gain is flat between $993-997 \mathrm{~nm}$, e.g. for a $10 \%$ output coupler $(\beta=0.065)$, the laser operates simultaneously at 997.1, 994.2 and $993.0 \mathrm{~nm}$. At higher inversion levels $(\beta>0.08)$ the laser operates around $992 \mathrm{~nm}$ : for an output coupler of $15 \%(\beta=0.09)$ or higher the laser wavelength lies between 992.7 and $992.0 \mathrm{~nm}$.

The best CW laser performance at $992 \mathrm{~nm}$ has been obtained with the $15 \%$ OC $(\beta=0.11)$ with a laser emission of $33 \mathrm{~W}$ for $93 \mathrm{~W}$ absorbed pump power (under laser operation). The laser efficiency is then $35 \%$ (Fig. 3b). The measured small signal gain is found to be equal to 2.7.

The laser and pump emission wavelengths were measured simultaneously. Figure $1 \mathrm{~b}$ reports these pump and laser wavelengths at the maximum output power. On the same graph the gain cross section is also plotted for the value $\beta=0.1$ corresponding to the optimal power. The predominance of the gain at $992.0 \mathrm{~nm}$ clearly appears, corroborating the experimental results. The mean emission wavelength is $992.7 \mathrm{~nm}$ and the mean pump wavelength is $980.7 \mathrm{~nm}$, which corresponds to a very low laser quantum defect $\eta_{Q D}$ laser $=1-\lambda_{\mathrm{p}} / \lambda_{\mathrm{L}}=1.2 \%$. Those results clearly indicate the strong potential of $\mathrm{Yb}: \mathrm{CaF}_{2}$ used at cryogenic temperature for high power laser developments where efficiency and heat load are an issue.

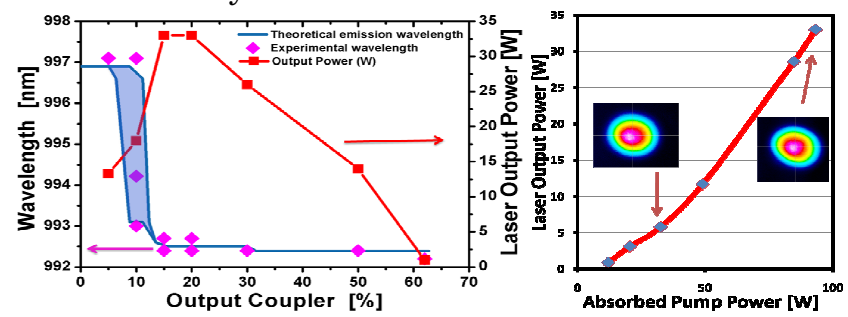

Fig. 3a : Experimental and theoretical emission wavelengths and laser power obtained for different output couplers. 3b: Corresponding laser power (at optimum) vs absorbed pump power at $981 \mathrm{~nm}$ obtained with a $15 \%$ OC and associated beam profiles at low and high powers.

It is interesting to note that for broadband amplification (992-997 nm), the optimal operation should be obtained at low inversion levels.

Exploiting such small quantum defect configuration might be challenging and it is worth considering a number of points. It is important to identify that thermal loads in ytterbium-doped laser materials come from three types of non-radiative relaxations: the laser quantum defect ( $\mathrm{nQD}$ laser $=1.2 \%$ ) between pump and laser photons, the fluorescence quantum defect ( $\mathrm{n}_{\mathrm{QD}}$ fluo $=1-\lambda_{\mathrm{p}} / \lambda_{\mathrm{F}}=3.1 \%$ ) between the pump and fluorescence photons and non radiative desexcitations from ${ }^{2} \mathrm{~F}_{5 / 2}$ to ${ }^{2} \mathrm{~F}_{7 / 2}$ levels, evaluated in our case to $0.7 \%$ of the absorbed pump photons [12]. Then, $1.2 \% \times 35 \%(35 \%=$ laser efficiency) of these absorbed pump photons heats the crystal by laser quantum defect and $3.1 \% \times 64 \%$ by fluorescence quantum defect. Consequently, for a total absorbed pump power of $93 \mathrm{~W}$, this leads respectively to $0.65 \mathrm{~W}, 0.39 \mathrm{~W}$ and $1.85 \mathrm{~W}$ (total of $2.9 \mathrm{~W}$ ).

This clearly indicates that in a small quantum defect laser the thermal loads due to the fluorescence quantum defect cannot be neglected. Therefore, the laser efficiency directly impacts on the thermal loads. In our experiement, the efficiency is limited by the losses providing from the not fully-ideally-coupled cavities of the uncoated facet of the crystal and/or to residual pollution due to our nonperfect cryostat vacuum.

The second issue to be considered, especially at high pump power, is the thermal conductivity of the laser material. From this point of view, $\mathrm{Yb}: \mathrm{CaF}_{2}$ is particularly interesting since its thermal conductivity at $\mathrm{LN}_{2}$ temperature rises up to $68 \mathrm{~W} / \mathrm{m} / \mathrm{K}$ for an undoped material[11] and to $23 \mathrm{~W} / \mathrm{m} / \mathrm{K}[5]$ for a $2.2 \% \mathrm{Yb}$-doped one. 
This means that the thermal loads can be efficiently evacuated and that the thermal lensing effects should be greatly reduced. This is clearly what we noticed in our experiments since no thermal lensing effect was observed even at full pump power (Fig. 3b).

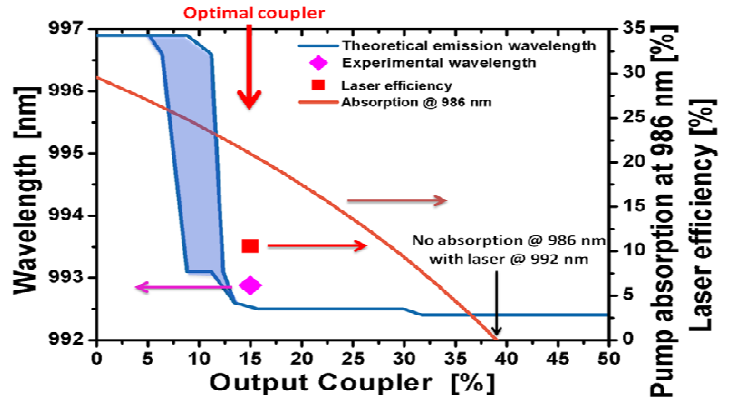

Fig. 4 : Theoretical emission wavelength and theoretical percentage of absorbed pump power at $986 \mathrm{~nm}$ versus $\beta$. Experimental laser wavelength and laser efficiency have been plotted for the optimal value $\beta=0.09$ ( $15 \%$ OC).

A last point which can be noticed by examining the gain cross section for $\beta=0.1$ reported in the figure 1 is the absorption line at $986 \mathrm{~nm}$ in order to decrease further the laser quantum defect. As plotted in the figure 4, the theoretical absorption of our crystal at $986 \mathrm{~nm}$ (for a single pump pass) is only $30 \%$ at maximum (and without saturation) and becomes null for $\beta=0.21$ (or equivalently for a laser at $992 \mathrm{~nm}$ and with $\mathrm{T}_{\mathrm{oc}}=39 \%$ ). On the other hand, we have to remember that there is also a constraint for $\beta$ to emit at $992 \mathrm{~nm}$. As a matter of fact, the optimal inversion population was found around 0.09 which corresponds in our case to an output coupler of $15 \%$. The experiment was performed and we obtained a laser output power of $4 \mathrm{~W}$ for an absorbed pump power of $35 \mathrm{~W}$ (efficiency of $11 \%$ ). The laser wavelength (Fig. $1 \mathrm{~b}$ and Fig. 4) was $992.9 \mathrm{~nm}$, leading to a low quantum defect of $0.7 \%$.

In conclusion, we have demonstrated, simultaneously for the first time, a low quantum defect, highly efficient and high-power laser operation of an $\mathrm{Yb}: \mathrm{CaF}_{2}$ laser crystal at cryogenic temperature. This represents an important step towards practical lasers based on $\mathrm{Yb}: \mathrm{CaF}_{2}$ operating at very high power levels. As a matter of fact, by using the simple figure of merit given by the ratio (thermal conductivity)/(quantum defect), we find record values of $5700 \mathrm{~W} / \mathrm{m} / \mathrm{K}$ for pumping around $981 \mathrm{~nm}$ and $9700 \mathrm{~W} / \mathrm{m} / \mathrm{K}$ around $986 \mathrm{~nm}[14]$. Moreover, $\mathrm{Yb}: \mathrm{CaF}_{2}$ really appears as a favorable material for such a kind of low quantum-defect laser operation (more than any other material) because of the existence of this sharp emission peak around $992 \mathrm{~nm}$ with a substantially high emission cross section. Such a peak does not exist in a system like $\mathrm{Yb}$ :CALGO [15], Yb:KGdLu(WO $\left.\mathrm{WO}_{4}\right)$ [17], materials which also gave rise to a very low-quantum defect laser operation, but with a much lower laser efficiency. Such a peak exists in the case of $\mathrm{Yb}: \mathrm{YLF}$ [18]. However, the lowest quantum defect which could be (theoretically) obtained would be around $2 \%$ and the one achieved so far, by pumping around $960 \mathrm{~nm}$ (which is not a common diode wavelength) was around $3.5 \% . \mathrm{Yb}: \mathrm{CaF}_{2}$ has then this rare property of having clear peaks very close to the zerophonon-line, which is very auspicious to efficient ultra- low-quantum-defect diode-pumped laser. Moreover concerning absorption improvement, this can be done using pump-recycling such as in thin disks.

The authors gratefully acknowledge financial support from the Program "Femtocryble" of Agence Nationale de la Recherche and the contract ILE 07-CPER 017-01.

1. P. P. Sorokin and M. J. Stevenson, Phys. Rev. Lett. 12 (5) 557-559 (1960).

2. Junji Kawanaka, Koichi Yamakawa, Hajime Nishioka, and Ken-ichi Ueda, Opt. Lett. 28, 2121-2123 (2003).

3. L. E. Zapata, D. J. Ripin, and T. Y. Fan Opt. Lett. 35 (11) 1854 (2010).

4. A. Pugžlys, G. Andriukaitis, D. Sidorov, A. Irshad, A. Baltuška, W. J. Lai, P.B. Phua, L. Su, J. Xu, H. Li, R. Li, S. Ališauskas, A. Marcinkevicius, M. E. Fermann, L. Giniunas, R. Danielius, Appl. Phys. B. 97 (2), 339-350 (2009).

5. S. Ricaud, D. N. Papadopoulos, P. Camy, J. L. Doualan, R. Moncorgé, A. Courjaud, E. Mottay, P. Georges, F. Druon Opt. Lett. 35, 3757-3759 (2010).

6. C. Catlow, A. Chadwik, G. Greaves, L. Moroney, Nature 312, 601-604 (1984) and refs therein.

7. V. Petit, J. L. Doualan, P. Camy, V. Ménard, and R. Moncorgé, Appl. Phys. B 78, 681-684 (2004).

8. M.L. Falin, K.I. Gerasimov, V.A. Latypov, A.M. Leushin, H Bill, D. Lovy, J. Lumin. 102-103, 269 (2003).

9. M. Ito, C. Goutaudier, Y. Guyot, K. Lebbou, T. Fukuda, G. Boulon, J. Phys. Cond. Mat. 16, 1501-1521 (2004).

10. V. Petit, P. Camy, J.L. Doualan, X. Portier, R. Moncorgé Phys. Rev. B 78 (8) 085131 (2008).

11. G. A. Slack, Phys. Rev. 122, 1451-1461 (1961).

12. J. Boudeile, J. Didierjean, P. Camy, J. L. Doualan, A. Benayad, V. Ménard, R. Moncorgé, F. Druon, F. Balembois, P. Georges, Opt. Expr. 16, 10098-10109 (2008).

13. A.Lucca, M. Jacquemet, F. Druon, F. Balembois, P. Georges, P. Camy, J.L. Doualan, R. Moncorgé, Optics Letters Vol. 29 1879-1881 (2004)

14. F. Friebel, F. Druon, J. Boudeile, D. N. Papadopoulos, M. Hanna, P. Georges, P. Camy, J. L. Doualan, A. Benayad, R. Moncorgé, C. Cassagne, and G. Boudebs, Opt. Lett. 34, 1474-1476 (2009)

15. M. Siebold, M. Hornung, R. Boedefeld, S. Podleska, S. Klingebiel, C. Wandt, F. Krausz, S. Karsch, R. Uecker, A. Jochmann, J. Hein, M. C. Kaluza, Opt. Lett. 33 (23) 27702772 (2008)

16. S. Ricaud, F. Druon, D. Papadopoulos, P. Camy, J-L. Doualan, R. Moncorgé, M. Delaigue, A. Courjaud, P. Georges, E. Mottay, Opt. Lett. 35, 2415-2417 (2010).

17. J. Hellström, B. Jacobsson, V. Pasiskevicius, and F. Laurell, Opt. Expr. 15, 13930-13935 (2007).

18. J. Petit, P. Goldner, B. Viana, J. Didierjean, F. Balembois, F. Druon and P. Georges, ASSP 2006 (OSA), paper WD1.

19. D. Geskus, S. Aravazhi, K. Wörhoff, M. Pollnau, Opt. Expr. 18 (25) 26107-26111 (2010). 


\section{Complete references:}

[1] P. P. Sorokin and M. J. Stevenson "Stimulated infrared emission from trivalent uranium ", Phys. Rev. Lett. 12 (5) 557-559 (1960), S.E. Hatch, W.F. Parsons, R.J. Weafgley, "Hot-pressed polycrystalline $\mathrm{CaF}_{2}: \mathrm{Dy}^{2+}$ laser," Appl. Phys. Lett. 5, 153 (1964).

[2]Junji Kawanaka, Koichi Yamakawa, Hajime Nishioka, and Ken-ichi Ueda, "30-mJ, diode-pumped, chirped-pulse Yb:YLF regenerative amplifier," Opt. Lett. 28, 2121-2123 (2003).

[3] L. E. Zapata, D. J. Ripin, and T. Y. Fan "Power scaling of cryogenic Yb:LiYF 4 laser," Opt. Lett. 35 (11) 1854 (2010).

[4] A. Pugžlys, G. Andriukaitis, D. Sidorov, A. Irshad, A. Baltuška, W. J. Lai, P.B. Phua, L. Su, J. Xu, H. Li, R. Li, S. Ališauskas, A. Marcinkevicius, M. E. Fermann, L. Giniunas, R. Danielius "Spectroscopy and lasing of cryogenically cooled $\mathrm{Yb}, \mathrm{Na}: \mathrm{CaF}_{2}$," Appl. Phys. B. 97 (2), 339-350 (2009).

[5] S. Ricaud, D. N. Papadopoulos, P. Camy, J. L. Doualan, R. Moncorgé, A. Courjaud, E. Mottay, P. Georges, and F. Druon "Highly efficient, high power, broadly tunable, cryogenically cooled and diode-pumped $\mathrm{Yb}: \mathrm{CaF}_{2}$ laser" Opt. Lett. 35, 3757-3759 (2010).

[6] C. Catlow, A. Chadwik, G. Greaves, L. Moroney "Direct observation of the dopant environment in fluorites using EXAFS," Nature 312, 601-604 (1984) and refs therein.

[7] V. Petit, J. L. Doualan, P. Camy, V. Ménard, and R. Moncorgé, "CW and tunable laser operation of $\mathrm{Yb}^{3+}$ doped $\mathrm{CaF}_{2}$," Appl. Phys. B 78, 681-684 (2004).

[8] M.L. Falin, K.I. Gerasimov, V.A. Latypov, A.M. Leushin, H. Bill, D. Lovy, "EPR and optical spectroscopy of $\mathrm{Yb}^{3+}$ ions in $\mathrm{CaF}_{2}$ : an analysis of the structure of tetragonal centers," J. Lumin. 102-103, 269 (2003).

[9] M. Ito, C. Goutaudier, Y. Guyot, K. Lebbou, T. Fukuda, G. Boulon, "Crystal growth, Yb spectroscopy, concentration quenching analysis and potentiality of laser emission in $\mathrm{Ca}_{1-\mathrm{x}} \mathrm{Yb}_{\mathrm{x}} \mathrm{F}_{2+\mathrm{x}}$, 'J. Phys. Cond. Mat. 16, 15011521 (2004).

[10] V. Petit, P. Camy, J.L. Doualan, X. Portier, R. Moncorgé "Spectroscopy of $\mathrm{Yb}^{3+} \mathrm{CaF}_{2}$ : from isolated centers to clusters," Phys. Rev. B 78 (8) 085131 (2008).

[11] G. A. Slack, "Thermal Conductivity of $\mathrm{CaF}_{2}, \mathrm{MnF}_{2}$, $\mathrm{CoF}_{2}$, and $\mathrm{ZnF}_{2}$ Crystals," Phys. Rev. 122, 1451-1461 (1961).

[12] J. Boudeile, J. Didierjean, P. Camy, J. L. Doualan, A. Benayad, V. Ménard, R. Moncorgé, F. Druon, F. Balembois, and P. Georges, "Thermal behaviour of ytterbium-doped fluorite crystals under high power pumping," Opt. Expr. 16, 10098-10109 (2008).

[13] A.Lucca, M. Jacquemet, F. Druon, F. Balembois, P. Georges, P. Camy, J.L. Doualan, R. Moncorgé, "High power tunable diode-pumped Yb3+:CaF2 laser," Optics Letters Vol. 29 1879-1881 (2004)

[14] F. Friebel, F. Druon, J. Boudeile, D. N. Papadopoulos, M. Hanna, P. Georges, P. Camy, J. L. Doualan, A. Benayad, R. Moncorgé, C. Cassagne, and G. Boudebs, "Diode-pumped 99 fs $\mathrm{Yb}: \mathrm{CaF} 2$ oscillator," Opt. Lett. 34, 1474-1476 (2009)

[15] M. Siebold, M. Hornung, R. Boedefeld, S. Podleska, S. Klingebiel, C. Wandt, F. Krausz, S. Karsch, R. Uecker, A. Jochmann, J. Hein, M. C. Kaluza, "Terawatt diodepumped $\mathrm{Yb}: \mathrm{CaF}_{2}$ laser," Opt. Lett. 33 (23) 2770-2772 (2008).

[16] S. Ricaud, F. Druon, D. N. Papadopoulos, P. Camy, J.-L. Doualan, R. Moncorgé, M. Delaigue, Y. Zaouter, A. Courjaud, P. Georges, and E. Mottay, "Short-pulse and high-repetition-rate diode-pumped $\mathrm{Yb}: \mathrm{CaF}_{2}$ regenerative amplifier," Opt. Lett. 35, 2415-2417 (2010).

[17] Jonas E. Hellström, Björn Jacobsson, Valdas Pasiskevicius, and Fredrik Laurell, "Quasi-two-level Yb:KYW laser with a volume Bragg grating," Opt. Expr. 15, 13930-13935 (2007).

[18] J. Petit, P. Goldner, B. Viana, J. Didierjean, F. Balembois, F. Druon and P. Georges, "Quest of Athermal Solid-State Laser: Case of $\mathrm{Yb}: \mathrm{CaGdAlO}_{4}$," in Advanced Solid-State Photonics, Technical Digest (Optical Society of America, 2006), paper WD1.

[19] D. Geskus, S. Aravazhi, K. Worhoff, M. Pollnau, "High power, broadly tunable and low-quantum defect $\mathrm{KGd}_{1-\mathrm{x}} \mathrm{Lu}_{\mathrm{x}}\left(\mathrm{WO}_{4}\right)_{2}: \mathrm{Yb}^{3+}$," Opt. Expr. 18 (25) 26107-26111 (2010). 